\title{
Study on Growth and Yield Performance of High Yielding Rice (Oryza sativa L.) Varieties under Rainfed Lowland Condition of Nagaland
}

\author{
T. Jamir ${ }^{*}$ and T. Gohain
}

Dept. of Agronomy, School of Agricultural Sciences and Rural Development (SASRD), NU, Medziphema, Nagaland (797 106), India

\section{Corresponding Author}

T. Jamir

e-mail: temjennajamirchumu@gmail.com

\author{
Article History \\ Article ID: AR1848 \\ Received in $29^{\text {th }}$ September, 2017 \\ Received in revised form $6^{\text {th }}$ October, 2017 \\ Accepted in final form $7^{\text {th }}$ October, 2017
}

\begin{abstract}
Crop genotype plays a dominant role in crop production systems. They affect crop productivity by their higher yield potentials, resistance against insect pest and diseases under different climatic conditions. To evaluate different varieties of rice for their growth and yield characteristics, an experiment was conducted to investigate high yielding rice (Oryza sativa L.) varieties under rainfed lowland condition of Nagaland at Neiphrelie Colony, Chumukedima during the kharif season of 2016. The study treatments adopted were eleven rice varietiies viz., Ranjit, Bahadur, Aghonibora, Satyaranjan, Moniram, Kushal, Mulagabharu, Bokuljoha, Basundara, Piolee and Ketikijoha (HYV rice released by AAU) at a spacing of $20 \times 15 \mathrm{~cm}^{2}$ using 3-4 seedling hill-1. The experiment was set in Randomized block design (RBD) with three replications. Almost all the varieties were found to be semi-dwarf in nature. Data on various growth and yield parameters revealed that Satyaranjan produced higher number of tillers hill-1 (23.44), no. of panicle hill-1 (22), yield (59.96 q ha-1) and harvest index (43.70). The length of panicle was found highest in Moniram $(26.45 \mathrm{~cm})$ and lowest in Basundara $(21.51 \mathrm{~cm})$. Bokuljoha recorded highest straw yield $(94.38 \mathrm{q}$ $\mathrm{ha}^{-1}$ ) and lowest filled grain percentage (73.17) and test weight (10.87 g). Filled grain percentage was found highest in Ranjit (86.72) and the highest test weight was recorded in Aghonibora ( $26.01 \mathrm{~g}$ ). The rice varieties Satyaranjan ( $\left.59.96 \mathrm{q} \mathrm{ha}^{-1}\right)$, Ranjit ( $57.01 \mathrm{q} \mathrm{ha}^{-1}$ ) and Kushal ( $56.39 \mathrm{q} \mathrm{ha}^{-1}$ ) can be successfully cultivated under rainfed lowland condition of Nagaland.
\end{abstract}

Keywords: Growth, lowland rice, rainfed, yield

\section{Introduction}

Rice is the principal staple food crop of the world and rice production has so far kept pace with the growing population, principally due to cultivation of high-yielding, high-input demanding, and semi-dwarf varieties (Gnanamanickam, 2009). Rice is the world's leading food crop, cultivated over an area of about 161.1 mha (2016-17) with a production of about $480.13 \mathrm{mt}$. According to the forecast, the government of India has revealed that 2015-16 kharif rice production was at around $90.6 \mathrm{mt}$. Further, it has been stated that total rice planted area 2015-16 kharif rice crop stood at around 36.841 mha. It is the most important food crops of India covering over $1 / 4$ of the total cropped area (USDA, 2016-17).

Indian rice cultivation also faces the challenge of global warming and climate change. A significant share of the rice crop is produced in the coastal regions, which are susceptible to a rise in sea level. There are about 10,000 varieties of rice in the world out of which about 4,000 are grown throughout the country. There are about 50 varieties of hybrid rice, mostly developed by private seed companies, of which about 25 are popular in the market. High yielding varieties (HYV) have gained much importance over the past years due to the low yield and the over growing population of our country. However, the introduction of semi-dwarf rice varieties and the large-scale use of inputs like fertilizers and insecticides have changed the dynamics of pests and diseases of rice, increasing their incidence significantly in the recent years (Kumari et al., 2016). Efforts are also underway to develop transgenic rice varieties to incorporate resistance to various pests, diseases and abiotic stresses. TDRI (total drought response index) could also be enacted to select cultivars for drought tolerance in a given environment and develop rice varieties with early season drought tolerance (Singh et al., 2017). Lack of ideal high yielding varieties and slow adoption of improved varieties, non-availability/inadequate supply of high quality seeds, low to very low fertilizer use, poor crop emergence and crop stand leading to thinner plant population, slow and ineffective transfer of technology are the constraints in the rainfed areas (Das, 2015)

The present research was carried out using high yielding rice varieties of Assam. Serious attention was given to collect indigenous rice varieties of Assam including Sylhet (Now in 
Bangladesh) with the establishment of Rice Research Stations at Karimganj (1913); Titabar (1923). The stock of germplasm maintained in the research stations of Assam is still continuing to be in adequate and far from representation of the available land races of NE India (Ahmed, 2015). A number of scented and non-scented Farmers' Varieties (FVs) of rice are available in India in general and North eastern India in particular (Roy et al., 2014; Talukdar et al., 2012; Chakravorty and Ghosh, 2013). There is strong need that the local germplasm of scented and non-scented rice to be collected, preserved and characterized in detail (Chakrabarty et al., 2012). Also Alam et al. (2008) reported that among production factors varietal selection at any location has an important role. In Nagaland, the present area under wetland rice cultivation (WRC) is about 109,280 ha with a production of $298,920 \mathrm{mt}$ and productivity of about 2,739 $\mathrm{kg} \mathrm{ha}^{-1}$ (Anonymous, 2015).

\section{Materials and Methods}

\subsection{Details of experiment}

The experiment was carried in the foothill of Nagaland, Neiphrelie Colony, Chumukedima located at an altitude of 310 meters above mean sea level with geographical location at $25^{\circ} 45^{\prime} 43^{\prime \prime}$ North latitude and $95^{\circ}$ 53'04" East longitude. A total of 11 (HYV) rice varieties were studied under rainfed lowland condition of Nagaland. The high yielding rice varieties were collected from Assam Agricultural University, Jorhat viz., Ranjit, Bahadur, Aghonibora, Satyaranjan, Moniram, Kushal, Mulagabharu, Bokuljoha, Basundhara, Piolee and Ketikijoha. 3-4 rice seedlings hill-1 $^{-1}$ were transplanted at a spacing of $20 \times 15 \mathrm{~cm}^{2}$ with three replications and statistical analysis was carried out by following randomized block design (Gomez and Gomez, 1984).

The cultivars under taken during the present research are given below:

$\alpha)$ Ranjit (IET-12554): It was developed in the year 1992, from cross between Pankaj×Mahsuri, suitable for shallow water $(<30 \mathrm{~cm})$ submergence. It matures in 150-155 days, semi dwarf $(99 \mathrm{~cm})$, it has very good grain quality and potential to give $40 \mathrm{q} \mathrm{ha}^{-1}$.

$\beta$ ) Bahadur: It was developed in the year 1992, from cross between Pankaj×Mahsuri, suitable for shallow water submergence. It is semi-dwarf $(114 \mathrm{~cm})$ with compact panicle brown husk colour. It is tolerant to blast and lodging and is recommended for cultivation in Assam and Nagaland.

$\chi)$ Aghonibora: It was developed in the year 1992, from cross between GandhiboraxKmj 1-52-2. It is categorized under waxy glutinous rice varieties and has high yielding, high amylopectin content in grain. It has a potential to give 2-3 $\mathrm{t} \mathrm{ha}^{-1}$.

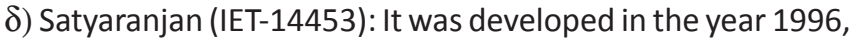
from cross between IET $9711 \times$ IET 11162, suitable for double cropped area. It is of medium duration 130-135 days, semi dwarf $(107 \mathrm{~cm})$. This variety is resistant to blast, gall midge and BLB. On an average it yields about $40 \mathrm{q} \mathrm{ha} \mathrm{h}^{-1}$. It preferably grows well under rainfed shallow lowlands and is most suited for Assam.

ع) Moniram (TTB 101-14): It was developed in the year 1992, from cross between Pankaj×Mahsuri, suitable for shallow water submergence. The duration of this variety is 150-155 days. It is semi-dwarf $(105 \mathrm{~cm})$ and blast tolerant.

ф) Kushal (IET-12552): It was developed in the year 1992, from cross between Pankaj×Mahsuri, suitable for shallow water submergence. Duration of this variety is 150-155 days, semidwarf $(116 \mathrm{~cm})$. It is preferably grown under rainfed medium lands and gives an average yield of $40 \mathrm{q} \mathrm{ha}^{-1}$ most suitable for Assam.

$\gamma)$ Mulagabharu: It is of medium duration 120-135 days and is of fine grain type. It is also gown as a Aus season with irrigation facility. It gives an average yield of 50-60 q ha-1.

$\eta)$ Bokuljoha: It has small grains, profuse tillering and long slender plant height. It is categorized under aromatic rice variety and yields on an average $2-3 \mathrm{t} \mathrm{ha}^{-1}$.

1) Basundhara (IET-14453): It was developed in the year 1996, from cross between IET $9711 \times$ IET 11162, suitable for double cropped area. It is of medium duration 130-135 days, plant is semi-dwarf $(113 \mathrm{~cm})$ and has medium sized grains. This variety is resistant to blast, BLB and gall midge and is suitable for rainfed shallow lowlands.

$\varphi)$ Piolee: It was developed in the year 1992, from cross between Pankaj×Mahsuri, suitable for shallow water submergence. It of good grain type.

к) Ketikijoha (IET-14390): It was developed in the year 1995, from cross between SavitrixBadshahbhog. It is the first HYV developed by AAU at RARS, Titabar with high yield potential and aroma. Duration of the crop is $140-150$ days. Grain is of medium size and is resistant to blast. It has the potential to yield 2-3 t ha-1.

\subsection{Biometrical parameters}

\subsubsection{Growth attributes}

Five hills were randomly selected in each plot and tagged for studying the parameter and their growth attributes were recorded accordingly. Plant height and number of tillers hill-1 were recorded at 30, 60 and 90 DAT.

\subsubsection{Yield attributes}

For assessing the yield attributes various parameters such as number of panicles, length of panicle, number of seed panicle $^{-1}$, filled grain percentage, test weight grain and straw yield and harvest index were recorded.

The formula used for calculating the filled grain percentage is given below:

Filled grain percentage $=\frac{\text { No. of filled grains }}{\text { Total no. of grains }} \times 100$ 
And for Harvest index

H.I $=\frac{\text { Economic yield }}{\text { Biological Yield }} \times 100$

\section{Results and Discussion}

\subsection{Effect of rice varieties on growth attributes}

\subsubsection{Plant height $(\mathrm{cm})$}

Plant height is one of the most important agronomic parameters in determining the growth of the plant. Recorded data and further assessment on successive plant growth stages revealed rapid elongation rate during the panicle initiation stage. Marked variations were observed in all stages i.e. 30, 60 and 90 DAT (Table 1). At 30 DAT the highest plant height was recorded in variety Bokuljoha $(73.22 \mathrm{~cm})$, while Ketikijoha was found to be at par. Similar results were proved by Rashid

\begin{tabular}{|c|c|c|c|c|c|c|}
\hline \multirow[t]{3}{*}{ Variety } & \multicolumn{3}{|c|}{ Plant height } & \multicolumn{3}{|c|}{ No. of tillers hill-1 } \\
\hline & 30 & 60 & 90 & 30 & 60 & 90 \\
\hline & DAT & DAT & DAT & DAT & DAT & DAT \\
\hline $\mathrm{V}_{1}$ & 63.34 & 97.67 & 138.33 & 9.22 & 17.78 & 15.44 \\
\hline $\mathrm{v}_{2}$ & 60.22 & 93.67 & 123.89 & 8.67 & 16.99 & 12.89 \\
\hline$v_{3}$ & 63.45 & 97.44 & 125.89 & 8.78 & 17.89 & 14.22 \\
\hline $\mathrm{V}_{4}$ & 64.44 & 101.44 & 133.44 & 13.44 & 27.11 & 23.44 \\
\hline $\mathrm{V}_{5}$ & 60 & 88.22 & 130.89 & 9.56 & 20.44 & 17 \\
\hline$V_{6}$ & 60.11 & 91.55 & 122 & 8.45 & 19.89 & 17.11 \\
\hline$v_{7}$ & 53.11 & 78.33 & 100.89 & 9.78 & 19.44 & 16.89 \\
\hline $\mathrm{V}_{8}$ & 73.22 & 102.33 & 142.22 & 8.22 & 20 & 18.11 \\
\hline$V_{9}$ & 56.44 & 87.11 & 109 & 8.44 & 19.89 & 16.11 \\
\hline$V_{10}$ & 57.11 & 80 & 108.78 & 10.56 & 22.22 & 20 \\
\hline $\mathrm{V}_{11}$ & 72.56 & 98.11 & 136.78 & 10.22 & 21.89 & 21.14 \\
\hline SEm \pm & 1.77 & 2.93 & 3 & 0.78 & 1.03 & 0.98 \\
\hline $\begin{array}{l}C D \\
(p=0.05)\end{array}$ & 6.07 & 10.06 & 10.29 & 2.66 & 3.52 & 3.37 \\
\hline
\end{tabular}

$\mathrm{V}_{1}$ : Ranjit; $\mathrm{V}_{2}$ : Bahadur; $\mathrm{V}_{3}$ : Aghonibora; $\mathrm{V}_{4}$ : Satyaranjan; $\mathrm{V}_{5}$ : Moniram; $\mathrm{V}_{6}$ : Kushal; $\mathrm{V}_{7}$ : Mulagabharu; $\mathrm{V}_{8}$ : Bokuljoha; $\mathrm{V}_{9}$ : Basundara; $\mathrm{V}_{10}$ : Piolee; $\mathrm{V}_{11}$ : Ketikijoha

et al. (2017) that scented varieties have taller plant heights as compared to other varieties. The lowest plant height at 30, 60 and 90 DAT was recorded in variety Mulagabharu. At 60 DAT the highest plant height was recorded in Bokuljoha $(102.33 \mathrm{~cm})$ while Satyaranjan, Ketikijoha, Ranjit, Aghonibora and Bahadur were found to be at par. At 90 DAT Satyaranjan, Ranjit and Ketikijoha were found to be at par with Bokuljoha $(142.22 \mathrm{~cm})$. This was also reported by Singh et al. (2013) where Satyaranjan recorded higher plant height as compared to other variety.

4.1.2. No. of tillers hill ${ }^{-1}$

Number of tillers hill-1 is a good indicator of good crop establishment methods as well as good growth and development. It greatly affects the yield potential of the crop. It was observed that there was significant difference in number of tillers hill ${ }^{-1}$ among the varieties. There was an increase in number of tillers hill ${ }^{-1}$ at 30 and 60 DAT where highest number of tillers hill ${ }^{-1}$ was observed during the panicle initiation stage. It was also found that after 60 DAT the number of tillers hill ${ }^{-1}$ slightly decreased among the varieties (Table 1). The number of tillers was increased as the vegetative growth of crop increased, but at later stages the number of tillers decreased due to improper utilization of radiation interception (Sharma et al., 2011). Satyaranjan recorded the highest number of tillers hill ${ }^{-1}$ in all the three stages. Bahadur consistently recorded lowest number of tillers hill ${ }^{-1}$ at 60 and 90 DAT. Ketikijoha (21.14) was found to be at par with Satyaranjan at 90 DAT.

\subsection{Effect of rice varieties on yield attributes}

\subsubsection{No. of panicles hill-1}

Different varieties significantly affected the number of panicle hill $^{-1}$. Number of panicles per unit area is the most important component of yield and contributes $89 \%$ of the variations in yield. The highest number of panicle hill ${ }^{-1}$ was observed in Satyaranjan (22). Varieties such as Piolee, Ketikijoha and Kushal were found to be at par with Satyaranjan (Table 2). The increase in number of panicle in a unit area showed an increase in yield (Satapathy et al., 2015). The effects of plant density of kernel dimension were also identified during different panicle development stages (Senanayake et al., 1991; Karim et al., 1992).

\subsubsection{Length of panicle $(\mathrm{cm})$}

The maximum panicle length was obtained from Moniram $(26.45 \mathrm{~cm}$ ) while Ketikijoha, Bahadur, Ranjit and Kushal and Satyaranjan were found to be at par (Table 2). Basundara recorded the lowest panicle length $(21.50 \mathrm{~cm})$. Such variations might be due to the genetic make-up of the varieties.

\subsubsection{No. of grains panicle $e^{-1}$}

Tyeb et al. (2013); Islam et al. (2012) reported that variety exerted variable effect on yield contributing characters of rice. The difference in variety showed significant difference in number of grains panicle ${ }^{-1}$ typically due to the difference in genetic material. Ranjit reorded highest number of grain panicle $^{-1}(166)$ while Moniram and Bahadur were found to be at par. Similar findings were proved by Subramani et al. (2014) where Ranjit recorded highest number of grains panicle $\mathrm{e}^{-1}$ among the other varieties. The lowest number of grain panicle ${ }^{-1}$ was recorded in Ketikijoha (86) (Table 2).

\subsubsection{Filled grain percentage (\%)}

The highest filled grain percentage was recorded in Ranjit $(86.72 \%)$. The result is in consistent with that of Subramani et al. (2014) where Ranjit recorded highest filled grain percentage. Kushal, Satyaranjan, Mulagabharu, Aghonibora and Moniram were found to be at par with Ranjit (Table 2). 


\begin{tabular}{|c|c|c|c|c|c|c|c|c|}
\hline Variety & $\begin{array}{c}\text { No. of } \\
\text { panicle } \\
\text { hill }^{-1}\end{array}$ & $\begin{array}{l}\text { Length of } \\
\text { panicle } \\
(\mathrm{cm})\end{array}$ & $\begin{array}{l}\text { No. of } \\
\text { grain } \\
\text { panicle }\end{array}$ & $\begin{array}{l}\text { Filled } \\
\text { grain \% }\end{array}$ & $\begin{array}{c}\text { Test } \\
\text { weight (g) }\end{array}$ & $\begin{array}{l}\text { Grain yield } \\
\left(q \text { ha }^{-1}\right)\end{array}$ & $\begin{array}{l}\text { Straw yield } \\
\left(q \mathrm{ha}^{-1}\right)\end{array}$ & $\begin{array}{c}\text { Harvest } \\
\text { index (\%) }\end{array}$ \\
\hline $\mathrm{V}_{1}:$ Ranjit & 14 & 25.36 & 166 & 86.72 & 20.06 & 57.01 & 90.95 & 38.34 \\
\hline $\mathrm{V}_{2}:$ Bahadur & 12 & 25.95 & 134 & 76.78 & 22.67 & 47.77 & 64.95 & 42.5 \\
\hline$V_{3}$ : Aghonibora & 14 & 22.99 & 125 & 81.27 & 26.01 & 54.89 & 73.82 & 42.61 \\
\hline $\mathrm{V}_{4}$ : Satyaranjan & 22 & 24.41 & 125 & 82.38 & 20.97 & 59.96 & 77.19 & 43.72 \\
\hline $\mathrm{V}_{5}:$ Moniram & 15 & 26.45 & 139 & 77.36 & 20.92 & 54.47 & 80.29 & 40.45 \\
\hline $\mathrm{V}_{6}:$ Kushal & 19 & 25.02 & 115 & 85.6 & 21.2 & 56.39 & 76.75 & 42.29 \\
\hline $\mathrm{V}_{7}$ : Mulagabharu & 14 & 23.94 & 116 & 81.36 & 15.95 & 44.23 & 73.08 & 37.56 \\
\hline $\mathrm{V}_{8}:$ Bokuljoha & 17 & 23.39 & 121 & 73.17 & 10.87 & 38.38 & 94.38 & 28.9 \\
\hline $\mathrm{V}_{9}$ : Basundara & 14 & 21.51 & 121 & 68.2 & 23.69 & 52.85 & 72.26 & 42.21 \\
\hline $\mathrm{V}_{10}:$ Piolee & 20 & 22.33 & 96 & 76.12 & 18.71 & 52.03 & 75.51 & 40.59 \\
\hline $\mathrm{V}_{11}:$ Ketikijoha & 20 & 26.33 & 86 & 74.91 & 17.52 & 45.48 & 91.72 & 33.17 \\
\hline $\mathrm{SEm} \pm$ & 1.12 & 0.68 & 9.87 & 2.89 & 1.24 & 4.24 & 4.32 & 2.1 \\
\hline $\mathrm{CD}(p=0.05)$ & 3.84 & 2.34 & 33.81 & 9.91 & 4.26 & 14.52 & 14.82 & 7.26 \\
\hline
\end{tabular}

Filled grain percentage is affected by the degree of grain set as well as the early stage of grain growth Tsuneo Kato (2010). The lowest filled grain percentage was recorded in Bokuljoha (73.17\%). The poor grain filling in rice is the result of poor translocation and partitioning of assimilates into grains (sink) rather than of limited biomass production or source limitation (Puteh et al., 2014).

\subsubsection{Test weight $(g)$}

It is an indicator of general grain quality and primary grain specification. Test weight was found to be significant in the varying varieties. Satapathy and Nanda (1997), Xin et al. (2000) reported that 1000 -grain weight significantly varied with different varieties. The grains of Aghonibora recorded the highest 1000-grain weight (26.01 g) Singh et al. (2013). This might be due to effective utilization of nutrients and also due to size of the grains. While Basundara and Bahadur were found to be at par with Aghonibora (Table 2).

\subsubsection{Grain yield $\left(q h^{-1}\right)$}

Grain yield is one of the most important parameter in determining the potential of a variety. The highest grain yield was recorded in Satyaranjan ( $\left.59.96 \mathrm{q} \mathrm{ha}^{-1}\right)$. Similar results were proved by Subramani et al. (2014). The lowest grain yield was recorded in Bokuljoha ( $38.38 \mathrm{q} \mathrm{ha}^{-1}$ ) due to its small and fine grain quality. Similar results were found elsewhere (Tyeb et al., 2013; Islam et al., 2012), who reported that variety exerted variable effect on yield and yield contributing characters of rice. Bai et al. (1992) reported that grain yield was found to be positively correlated with number of productive tillers hill-1, number of grains panicle ${ }^{-1}$ both at genotypic and phenotypic level. Rao et al. (2000) also reported that maximum grain yield is associated with higher dry matter, heavier panicle and number of total grains panicle ${ }^{-1}$. The findings of present investigation were in close conformity with Pradhan et al. (2014), whose findings revealed that grain yield was found to be positively correlated with panicles $\mathrm{m}^{-2}$, number of grains panicle ${ }^{-1}$ and panicle length (Table 2).

\subsubsection{Straw yield ( $\left.q h^{-1}\right)$}

Plant stature and tillering habit of the variety mainly had impact on the straw yield. The straw yields depend on environmental and genetic factors like variety, season, location, plant-height, soil texture and fertility, plant density, available water, fertilizer, weeds and their control, harvesting stage and methods. The highest straw yield was recorded in Bokuljoha (94.38 q ha-1) which was mainly due to its profuse growth and taller plant height. Ketikijoha, Ranjit and Moniram were found to be at par with Bokuljoha. The lowest straw yield was recorded in Bahadur ( $64.95 \mathrm{q} \mathrm{ha}^{1}$ ) (Table 2). Semi-tall and tall varieties produce relatively more straw than the dwarf varieties. Due to the semi-dwarf character of Bahadur rice variety and low tillering nature of the plant it was recorded to have a lower straw yield comparing to other varieties.

\subsubsection{Harvest index (\%)}

The increase in grain yield is because of higher dry matter production due to higher seedling vigour leading to quicker growth rate and higher harvest index. In the present study, the higher number of panicles hilll-1 and grain yield was complying with higher harvest index in the rice varieties. Wiangsamut et al. (2013) described that the variability of genotypes in their ability to partition dry matter and the superiority of rice varieties, are well categorized with the sink strength and harvest index. Sinclair (1998) stated that harvest index has been an important feature related with the increase in crop 
yield during the $20^{\text {th }}$ century. The highest harvest index was recorded in variety Satyaranjan (43.72\%). The lowest harvest index was recorded in Bokuljoha (28.90\%) (Table 2). Similar findings were proved by Singh et al. (2013). Bokuljoha being a fine grain-type, scented variety resulted in lower yield and thus recorded the lowest harvest index (\%). The decrease or low harvest index was due to higher straw yield (Hussain et al., 2014).

\section{Conclusion}

All the low land rice varieties tested under Nagaland condition performed well both in growth and yield. However, considering grain yield, Satyaranjan (59.96 q ha ${ }^{-1}$ ), Ranjit (57.01 $\mathrm{q} \mathrm{ha}{ }^{-1}$ ) and Kushal (56.39 q ha-1) were found suitable under rainfed lowland condition of Nagaland.

\section{References}

Anonymous, C., 2015. Nagaland Economic survey. Directorate of Economics and Statistics, Government of Nagaland, Kohima, India, 46.

Ahmed, T., 2015. Detailed proposal on scented rice of the north east regions. Biodiversity Studies of Joha Rice of North East India, 05-13.

Alam, M., Hasanuzzaman, M., Nahar, K., 2008. Growth pattern of three high yielding rice varieties under different Phosphorus levels. Advances in Biological Research 3(3-4), 110-116.

Bai, R., Ahmed, N.R., Devira, R., Joseph, C.A., 1992. Genetic variability and association of characters in medium duration rice genotypes. Oryza 29, 19-22.

Chakrabarty, S.K., Joshi, B.D., Singh, M.A., Maity, S., Vashisht, A., Dadlani, M., 2012. Characterization and evaluation of variability in farmers' varieties of rice from West Bengal. Indian Journal Plant Genetic Resource 72(2), 136-142.

Chakravorty, A., Ghosh, P.D., 2013. Characterization of landraces of rice from Eastern India. Indian Journal Plant Genetic. Resource 26(1), 62-67.

Das, M., 2015. Studies on crop establishment methods, cropping systems and varieties in submergence prone rainfed lowland rice ecosystem, M.Sc. (Agri.), Thesis on Agronomy, Institute of Agricultural Sciences Banaras Hindu University, Varanasi.

Gnanamanickam, S.S., 2009. Rice and its importance to human life Program. Biol Con, 8, 1-11.

Gomez, K.A., Gomez, A.A., 1984. In: Statistical procedures for agricultural research: An IRRI Book. A Wiley-Interscience Publication, Joh Wiley \& Sons, New York, USA, 680.

Hussain, S., Fujii, T., McGoey, S., Yamada, M., Ramzan, M., Akma, I.M., 2014. Evaluation of different rice varieties for growth and yield characteristics. The Journal of Animal \& Plant Sciences 24(5), 1504-1510.

Islam, M.S., Sarkar, M.A.R., Uddin, S., Parvin, S., 2012. Yield of Fine Rice Varieties as Influenced by Integrated Management of Poultry Manure, Urea Super Granules and Prilled Urea. Journal of Environmental Science and Natural Resources 5(1), 129-132.

Karim, M.A.A., Ali, S.S., Ali Mohammed, A., Majid, A., Akhtar, T.A., 1992. Effect of plant density on rice grain quality. International Rice Research. Newsletter 17, 12.

Kumari, K.A., Durgarani, C.V., Sattura, V., Sundaram, R.M., 2016. Marker-assisted pyramiding of genes conferring resistance against bacterial blight and blast diseases into indian rice variety MTU1010. Rice Science 23(6), 303-316.

Pradan, A., Thakur, A., Sonboir, H.L., 2014. Response of rice (Oryza sativa) varieties to different levels of nitrogen under rainfed aerobic ecosystem. Indian Journal of Agronomy 59(1), 76-79.

Puteh, A.B., Mondal, M.M., Ismail, M.R., Latif, M.A., 2014. Grain sterility in relation to dry mass production and distribution in rice (Oryza sativa L.). BioMed Research International. Article ID 302179, 1-6.

Rao, B.B., Modh, C.H., Ikramullah and Murthy, R., 2000. Influence of time of planting on grain yield of scented rice. Crop research 20(2), 179-181.

Rashid, M.M., Ghosh, A.K., Roni, M.N., Islam, M.R., Alam, M.M., 2017. Yield performance of seven aromatic rice varieties of Bangladesh. International Journal of Agriculture and Environmental Research 3(2), 2637-2642.

Roy, S., Banerjee, A., Pattanayak, A., Roy, S.S., Rathi, R.S., Misra, A.K., 2014. Chakhao (delicious) rice landraces (Oryza sativa L.) of North-east India: collection, conservation and characterization of genetic diversity. Plant Genetic Resource 12, 264-272.

Satapathy, D., Nanda, A.K., 1997. Inter-relationship between yield and some associated characters in upland rice growing under rainfed condition. Oryza 15(1), 14-18.

Satapathy, B.S., Singh, T., Pun, K.B., Rautaray, S.K., 2015. Evaluation of rice (Oryza sativa) under double transplanting in rainfed lowland rice ecosystem of Asom. Indian Journal of Agronomy 60(2), 245-248.

Senanayake, N., De Datta, S.K., Naylor, R.E.L., Thompson, W.J., 1991. Lowland rice apical development stages and cultivar differences detected by electron microscopy. Agronomy Journal 83, 1013-1023.

Sharma, A., Dhaliwal, L.K., Sandhu, S.K., Singh, S.P., 2011. Effect of plant spacing and transplanting time on phenology, tiller production and yield of rice (Oryza sativa L). International Journal of Agricultural Sciences 7(2), 249-253.

Sinclair, T.R., 1998. Historical changes in harvest index and crop nitrogen accumulation. Crop Science 38, 638-643.

Singh, B., Reddy, K.R., Redona, E.D., Walker, T., 2017. Screening of rice cultivars for morphophysiological responses to early-season soil moisture stress. Rice Science 24(6), 322-335.

Singh, D., Bhaskar, B.P., Baruah, U., Sarkar, D., 2013. Soil analogy for making varietal and fertilizer recommendations for 
rice (Oryza sativa) cultivars in Brahmaputra valley of Asom. Indian Journal of Agronomy 58(4), 512-516.

Subramani, T., Raja, R., Ambast, S.K., Ravishankar, N., Ahmed, S.K.Z., Damodaran, V., Bommayasamy, N., 2014. Evaluation of long duration rice varieties for enhancing productivity under Island ecosystem. Journal of the Andaman Science Association 19(1), 14-18.

Talukdar, P.R., Sharma, A., Rathi, S., Sarma, S., 2012. Genetic diversity of rice of Singpho community of Assam. Indian Journal Plant Genetic Resource 25(3), 274-280.

Tsuneo, K., 2010. Variation and association of the traits related to grain filling in several extra-heavy panicle type rice under different environments. Plant Production Science 13 (1), 185-192.

Tyeb, A., Paul, S.K., Samad, M.A., 2013. Performance of variety and spacing on the yield and yield contributing characters of transplanted aman rice. Journal of Agroforestry and Environment 40(4), 595-597.

USDA. 2016-17. Available at: https://www.statista.com.

Vavilov, N.I., 1926. Studies on the origin of cultivated plants. Bulletin of applied Botany, Genetics and Plant Breeding. 16(2), 1-48.

Watt, G., 1892. Dictionary of the Economic Products of India 5, 502.

Wiangsamut, B., Lafarge, T.A., Mendoza and Pasuquin, E.M., 2013. Agronomic traits and yield components associated with broadcasted and transplanted high-yielding rice genotypes. Esci Journal of Crop Production 2(1), 19-30.

Xin, Y.N., Zhang, L.X., Zhang, Y., Yaxian, Y., 2000. Approach to HY culture techniques of direct sown rice in Shanghai 15(4), 34-40. 